\title{
Variability of mango accessions resistance to dieback disease caused by Lasiodiplodia theobromae and Neofusicoccum parvum
}

\author{
1 State University of Feira de Santana, Feira de Santana - BA, Brazil \\ 2 Brazilian Agricultural Research Corporation (Embrapa Semiarid), Petrolina - PE, Brazil
}

Washington C. P. Coelho ${ }^{1}$, Carlos Antonio F. Santos ${ }^{(D 2}{ }^{2}$ and Diógenes da C. Batista ${ }^{2}$

Received: 09 February, 2020. Accepted: 26 March, 2020

First published on the web April, 2020

Doi: 10.26545/ajpr.2020.b00055x

\begin{abstract}
Mango growing is one of the main agricultural activities in the fruit sector in Brazil for the internal and export market. The crop is subject to damage caused by the fungi Lasiodiplodia theobromae and Neofusicoccum parvum, especially mango dieback disease, which limits the yield and longevity of the mango tree. In spite of the importance of these pathogens, studies regarding sources of resistance in mango are rare. The aim of this study was to evaluate 75 accessions of mango available in the germplasm bank regarding resistance to the fungi $L$. theobromae and $N$. parvum to support breeding programs for mango growing. Evaluations were carried out from Apr 2016 to Mar 2018. Conidia suspensions of $10^{4}$ conidia $\mathrm{mL}^{-1}$ of L. theobromae or $N$. parvum were applied with a manual sprayer on young branches. Accessions were considered resistant when disease symptoms were absent on more than $90 \%$ of the branches at three different periods of inoculation. Thirty-three accessions showed resistance to $L$. theobromae and 19 accessions showed resistance to $N$. parvum. Six accessions were most susceptible $(<50 \%)$ to $L$. theobromae, whereas 25 accessions were most susceptible to N. parvum. The accessions 'Apple DCG', 'Ataulfo', 'Da porta', 'Dashehari', 'Espada', 'Haden', 'Haden 2H', 'Heidi', 'Irwin', 'Keitt', 'Kent', 'Néldica', 'Recife', and 'Smith' showed resistance to the two pathogens and can be used as sources of resistance to the two fungi in mango breeding studies, or these accessions can even be recommended for use as commercial cultivars.
\end{abstract}

Key-words: Mangifera indica, Botryosphaeriaceae, Germplasm

\section{Introduction}

Mango (Mangifera indica L.) is the fresh fruit most consumed in the world, and demand has more than doubled in the last three decades (Siddiq et al., 2017). The semiarid region around the São Francisco river valley belonging to the states of Bahia and Pernambuco is responsible for $85 \%$ of Brazilian exports (Anuário Brasileiro da Fruticultura, 2017). Growing mango requires a good level of plant health control measures against pests and diseases, seeking to meet the requirements of the Brazilian market, and especially the foreign market, regarding fruit quality in relation to appearance, as well as in relation to levels of agricultural chemical residues. Diseases caused by complex of Botryosphaeriaceae, represent risks in production and sale of mango (Costa et al., 2010; Marques et al., 2013; Terao et al., 2016).

Dieback disease is among the main symptoms observed in plants infected by Lasiodiplodia theobromae (Pat.) Griffon \& Maubl and Neofusicoccum parvum Pennycook \& Samuels. Normally, in sick plants without any human intervention, the symptoms evolve to the decline 
and death of the plants (Batista et al., 2017). Mango trees with symptoms of dieback must undergo mechanical and manual operations through pruning to restore plant health, and this makes the process more expensive, because it is not possible to cure the plant through fungicide applications alone. In spite of the more than one thousand varieties of mango in the world (Siddiq et al., 2017) and the diverse problems caused by $L$. theobromae and $N$. parvum, studies of genetic resistance, as a component for management of dieback disease, have not been fully explored in the mango agronomic characterization, or these studies lack continuity. In this perspective, triages performed in the Active Germplasm Bank (AGB) to identify mango accessions resistant to dieback disease are useful when the breeder desires to incorporate this trait in development of new mango varieties. Some studies have been conducted for purpose of exploring genetic resistance in management of mango dieback disease (Coelho et al., 2018; Khanzada et al., 2015; Ramos et al., 1997). In breeding programs, obtaining varieties with a reaction of resistance to different pathogens is quite desirable. It is the most efficient control method, due to lower production costs from control of pathogens and to less aggression to the environment through reduction in the use of fungicides (Yorinori and Kiihl, 2001). Aim of study was to evaluate mango accessions for resistance to the fungi $L$. theobromae and $N$. parvum, to support breeding programs.

\section{Materials and Methods}

Seventy-five accessions of mango (Table 1), belonging to the AGB of Embrapa Semiarid, were evaluated between Apr 2016 and Mar 2018 for resistance to the fungi $L$. theobromae and $N$. parvum. The AGB is in the Mandacaru Experimental Field in the municipality of Juazeiro,

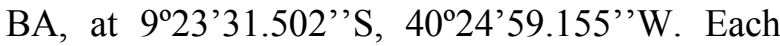
accession consists of four clones of approximately twenty-four years of age planted at a spacing of 10 $\mathrm{m} \times 10 \mathrm{~m}$ under a micro-sprinkler irrigation system.

Table 1. Origin of the 75 accessions of the Active Germplasm Bank of Embrapa Semiarid evaluated for the dieback disease in mango.

\begin{tabular}{llll}
\hline Accession & Origin & Accession & Origin \\
\hline 'Alfa' & Brazil & 'JuazeiroVI' & Brazil \\
'Amarelinha' & Brazil & 'Keitt' & USA \\
'Ametista' & Brazil & 'Kent' & USA \\
'AppleDCG' & Thailand & 'Langra' & India \\
'Ataulfo' & Mexico & 'Lita' & Embrapa \\
'Beta' & Brazil & 'M- 13269' & USA \\
'Black Java' & Australia & 'Malindi' & India \\
'Bonita' & Brazil & 'Manila',$~$ & ThePhilippines \\
'Bourbon' & Brazil & 'Manzanilo' & Mexico \\
'Brasil' & Brazil & 'Maya' & Mexico \\
'Carlotão' & Brazil & 'Momi-K' & USA \\
'Caxangá' & Brazil & 'Mon Amon DCG' & Thailand \\
'China' & Brazil & 'Morais' & Brazil \\
'Comprida Roxa' & Brazil & 'Nego não Chupa' & Brazil \\
'CPR' & Brazil & 'Néldica' & South Africa \\
'Da porta' & Brazil & 'Olour' & India \\
'Dama de Ouro' & Brazil & 'Ômega' & Brazil \\
'Dashehari' & India & 'Papo de Peru I' & Brazil \\
'Eldon' & USA & 'Parwin' & USA \\
'Espada' & Brazil & 'Pêssego' & Brazil \\
'Espada Itaparica' & Brazil & 'Pêssego DPV' & Brazil \\
'Espada Ouro' & Brazil & 'Pingo de Ouro DPV' & Brazil
\end{tabular}




\begin{tabular}{llll} 
'Espada 35' & Brazil & 'Pingo de Ouro' & Brazil \\
'Extrema' & Brazil & 'Primor de Amoreira' & Brazil \\
'Favo de Mel' & Brazil & 'Princesa' & Brazil \\
'Florigon' & USA & 'R2 E2' & Australia \\
'Foice' & Brazil & 'Recife' & Brazil \\
'Haden' & USA & 'Rosa' & Brazil \\
'Haden Rosa' & Brazil & 'Ruby' & USA \\
'Haden 2H' & Brazil & 'Salitre' & Brazil \\
'Heidi' & South Africa & 'Smith' & USA \\
'Irwin' & USA & 'Tommy Atkins' & USA \\
'Itamaracá' & Brazil & 'Torbet' & USA \\
'Itiuba' & Brazil & 'Tyler Premier' & USA \\
'Joa' & South Africa & 'Van Dyke' & USA \\
'Juazeiro II' & Brazil & 'Zill' & USA \\
'Juazeiro III' & Brazil & '65' & USA \\
'Juazeiro IV' & Brazil & - & - \\
\hline
\end{tabular}

Growth and reproduction of isolates of $L$. theobromae and $N$. parvum were obtained by culturing fungi in an agar-water culture medium in Petri dishes for fifteen days. Upon development of reproductive structures, conidia were extracted through removal of pycnidia present in the colonies to a mortar containing sterilized distilled water, followed by maceration of the pycnidia with a pestle. After that, the suspension was filtered; the conidia were counted in a Neubauer chamber; and the concentration of the suspension was adjusted to $10^{4}$ conidia $\mathrm{mL}^{-1}$. The isolates of $L$. theobromae and $N$. parvum used were originally obtained from the Micology Laboratory of the Federal Rural University of Pernambuco - UFRPE.

Plant material for individualized inoculation of each fungus was obtained by periodically pruning mature branches of clones of each mango accession. Upon emergence of branches, those containing young leaves were selected for inoculation of the pathogen through the conidia suspension by means of a manual sprayer. The inoculum suspension was sprayed on the branches and leaves of the accessions, without injuries, until it run off (Dhingra and Sinclair, 1995). After spraying of the inoculum suspension, plastic bags moistened with sterilized distilled water were used to form a wet chamber for 48 hours (Alfenas and Ferreira, 2007). To avoid burning of inoculated leaves and branches from solar radiation, the plastic bags were covered with paper bags. Development of dieback symptoms was evaluated five days after opening the wet chamber. This procedure was performed three times for the fungi $L$. theobromae and $N$. parvum at different periods and for each accession evaluated.

The method of analysis used for evaluation of the absence of symptoms was an adaptation of the infection percentage method developed by Valiela (1952), using the following equation:

$$
\mathrm{BWS}=\left(\frac{\mathrm{NBWS}}{\mathrm{TNBE}}\right) \mathrm{X} 100
$$

As in: $\mathbf{B W S}=$ Branches without symptoms NBWS $=$ Number of branches without symptoms TNBE $=$ Total number of branches evaluated $\mathrm{x} 100$.

Plants without disease symptoms on more than $90 \%$ of the branches in the mean of the three different periods of inoculation were considered resistant to the fungi $L$. theobromae and $N$. parvum.

\section{Results}

Evaluations of the differential reactions of the mango accessions for dieback disease showed development of characteristic symptoms of the disease, confirming the effectiveness of inoculation of the fungi L. theobromae and N. parvum (Figure 1). At the end of the evaluations, pruning of all the diseased branches was necessary to prevent development of lesions and contamination of healthy parts of the plant.

According to the mean obtained of the three inoculations at different times with the fungus $L$. theobromae, absence of symptoms (100\% healthy) 
of dieback was observed in the accessions 'Apple DCG', 'Dashehari', 'Espada', 'Espada Itaparica', 'Haden', 'Haden Rosa', 'Heidi', 'Irwin', 'Juazeiro VI', 'Kent', 'Malindi', 'Maya', 'Momi-K', 'Ômega', 'Pingo de Ouro', 'Princesa', 'Recife', 'Smith', and 'Van Dyke', which were considered resistant to the pathogen (Table 2).
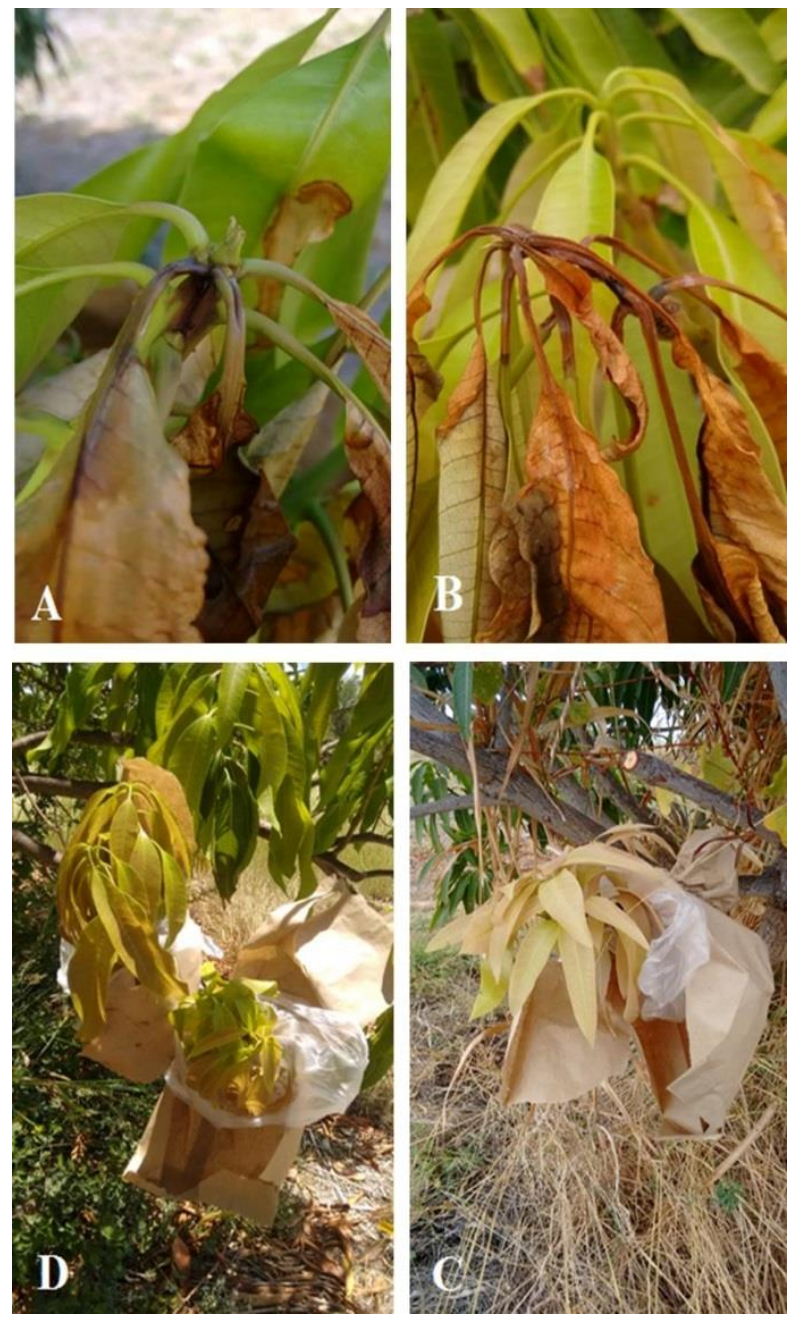

Fig. 1. Susceptibility in Tommy Atkins mango to dieback disease when inoculated with Lasiodiplodia theobromae (A) and Neofusicoccum parvum (B) and resistance of the Haden variety to the fungi $L$. theobromae (C) and N. parvum (D).
The following accessions were also considered resistant: 'Ataulfo', 'Black Java', 'Caxangá', 'Da porta', 'Haden 2H', 'Keitt', 'Lita', Haden 2H', 'Keitt', 'Lita', 'Manzanilo', 'Néldica', 'Pêssego DPV', 'R2 E2', 'Haden', and 'Rosa', because they developed few symptoms and the percentage of branches inoculated that did not develop symptoms was greater than $90 \%$. The accessions 'Bonita', 'Brasil', 'Carlotão', 'M13269', 'Pingo de Ouro DPV', and 'Zill' were most susceptible, with the lowest mean values of branches without symptoms, below 50\% (Table 2).

When the 75 accessions were inoculated with the fungus $N$. parvum at three different times, the following accessions did not develop symptoms of dieback on the branches inoculated with the pathogen: 'Alfa', Apple DCG', 'Ataulfo', 'Da porta', 'Espada', 'Espada Ouro', 'Haden', 'Haden 2H', 'Heidi', 'Irwin', 'Keitt', 'Kent', 'Mom Amon DCG', 'Néldica', 'Parwin', 'Recife', 'Smith', 'Torbet', and 'Tyler Primier'. They were considered resistant (Table 2). In addition, the accessions 'Dashehari' and 'Pingo de Ouro DPV' were considered resistant. The accessions that exhibited greatest susceptibility, with mean values of branches without symptoms below 50\%, were 'Amarelinha', 'Ametista', 'Bonita', 'Comprida roxa', 'Espada 35', 'Favo de mel', 'Foice', 'Itiúba', 'Joa', 'Juazeiro II', 'Juazeiro III', Juazeiro IV', 'Langra', 'M-13269', 'Manila', 'Morais', 'Nego não chupa', 'Olour', 'Ômega', 'Pêssego', 'Pingo de ouro', 'Primor de amoreira', 'Rosa', 'Tommy Atkins', and '65' (Table 2).

The accessions 'Apple DCG', 'Ataulfo', 'Da porta', 'Dashehari', 'Espada', 'Haden', 'Haden 2H', 'Heidi', 'Irwin', 'Keitt', 'Kent', 'Néldica', 'Recife', and 'Smith' were resistant to the two pathogens (Table 2). They are considered most promising for breeding studies or even for incorporation in commercial mango production systems. 
Table 2. Mean value of the branches without symptoms (MBWS), in percentage, in the three evaluations of mango accessions inoculated with Lasiodiplodia theobromae and Neofusicoccum parvum.

\begin{tabular}{|c|c|c|c|c|c|}
\hline \multirow[b]{2}{*}{ Accession } & \multicolumn{2}{|c|}{ (MBWS) } & \multirow[b]{2}{*}{ Accession } & \multicolumn{2}{|c|}{ (MBWS) } \\
\hline & $\begin{array}{c}L . \\
\text { theobromae }\end{array}$ & $\begin{array}{r}N . \\
\text { parvum }\end{array}$ & & $\begin{array}{c}L . \\
\text { theobromae }\end{array}$ & $\begin{array}{r}N \\
\text { parvum } \\
\end{array}$ \\
\hline 'Alfa' & 78 & 100 & 'Juazeiro VI' & 100 & 58 \\
\hline 'Amarelinha' & 89 & 33 & 'Keitt' & 93 & 100 \\
\hline 'Ametista' & 56 & 17 & 'Kent' & 100 & 100 \\
\hline 'Apple DCG' & 100 & 100 & 'Langra' & 67 & 33 \\
\hline 'Ataulfo' & 94 & 100 & 'Lita' & 92 & 65 \\
\hline 'Beta' & 89 & 67 & 'M-13269' & 44 & 33 \\
\hline 'Black Java' & 92 & 67 & 'Malindi' & 100 & 83 \\
\hline 'Bonita' & 39 & 33 & 'Manila' & 67 & 33 \\
\hline 'Bourbon' & 58 & 67 & 'Manzanilo' & 92 & 67 \\
\hline 'Brasil' & 20 & 67 & 'Maya' & 100 & 85 \\
\hline 'Carlotão' & 42 & 50 & 'Momi-K' & 100 & 83 \\
\hline 'Caxangá' & 91 & 50 & 'Mon Amon DCG' & 78 & 100 \\
\hline 'China' & 83 & 67 & 'Morais' & 78 & 40 \\
\hline 'Comprida Roxa' & 50 & 33 & 'Nego não Chupa' & 50 & 44 \\
\hline 'CPR' & 83 & 67 & 'Néldica' & 92 & 100 \\
\hline 'Da porta' & 93 & 100 & 'Olour' & 67 & 17 \\
\hline 'Dama de Ouro' & 67 & 73 & 'Ômega' & 100 & 39 \\
\hline 'Dashehari' & 100 & 93 & 'Papo de Peru I' & 67 & 67 \\
\hline 'Eldon’ & 50 & 83 & 'Parwin' & 83 & 100 \\
\hline 'Espada' & 100 & 100 & 'Pêssego' & 67 & 44 \\
\hline 'Espada Itaparica' & 100 & 50 & 'Pêssego DPV' & 96 & 50 \\
\hline 'Espada Ouro' & 60 & 100 & 'Pingo de Ouro DPV' & 33 & 94 \\
\hline 'Espada 35' & 50 & 33 & 'Pingo de Ouro' & 100 & 33 \\
\hline 'Extrema' & 79 & 67 & 'Primor de Amoreira' & 76 & 44 \\
\hline 'Favo de Mel' & 67 & 33 & 'Princesa' & 100 & 50 \\
\hline 'Florigon' & 56 & 83 & 'R2 E2' & 912 & 56 \\
\hline 'Foice' & 83 & 33 & 'Recife' & 100 & 100 \\
\hline 'Haden' & 100 & 100 & 'Rosa' & 94 & 33 \\
\hline 'Haden Rosa' & 100 & 89 & ‘Ruby’ & 62 & 63 \\
\hline 'Haden 2H' & 92 & 100 & 'Salitre' & 83 & 83 \\
\hline 'Heidi' & 100 & 100 & 'Smith' & 100 & 100 \\
\hline 'Irwin’ & 100 & 100 & 'Tommy Atkins' & 67 & 33 \\
\hline 'Itamaracá' & 89 & 69 & 'Torbet' & 50 & 100 \\
\hline 'Itiuba' & 67 & 33 & 'Tyler Premier' & 80 & 100 \\
\hline 'Joa' & 83 & 33 & 'Van Dyke' & 100 & 67 \\
\hline 'Juazeiro II' & 82 & 33 & 'Zill' & 44 & 78 \\
\hline 'Juazeiro III' & 63 & 48 & $' 65$ ' & 67 & 33 \\
\hline 'Juazeiro IV’' & 58 & 33 & - & - & - \\
\hline
\end{tabular}




\section{Discussion}

Diseases caused by $L$. theobromae and $N$. parvum compromise mango growing by limiting mango production, mango quality and plant longevity. In previous studies regarding inheritance of resistance in mango hybrids, the accessions 'Espada', 'Haden', and 'Keitt' were considered resistant to both pathogens (Coelho et al., 2018), corroborating the results of this study. In the evaluations of Khanzada et al. (2015) performed in Pakistan, most of the mango varieties developed symptoms of decline when challenged with $L$. theobromae. Nevertheless, the varieties 'Bagan Pali', 'Saroli', and 'Saleh Bhai' were identified as tolerant.

The varieties Tommy Atkins, Haden, Keitt, Kent, and Espada, without ordering for importance, are among those most grown in Brazil. These varieties show resistance to dieback disease caused by $L$. theobromae and $N$. parvum, except for Tommy Atkins. Tommy Atkins, which is often grown in Brazil, was susceptible to the two pathogens in the present study.

In addition to being the cause of dieback disease, the fungi $L$. theobromae and $N$. parvum can cause mango stem-end rot in post-harvest. In this case, the mango varieties 'Manguito' and 'Espada' were considered resistant, and 'Haden' and 'Rosa' moderately resistant to the fungus $L$. theobromae (= Botryodiplodia theobromae), reducing the severity of rotting of mango (Lima et al., 1998). The variety 'Keitt' was likewise considered resistant to rotting caused by $N$. parvum in the study of Batista et al. (2012), with inoculation on the fruit. Nevertheless, 'Favo-demel', 'Juazeiro VI', and 'Nego-não-chupa', which exhibited higher levels of resistance to rotting of mango in the study of Batista et al. (2012), were susceptible to dieback disease by $N$. parvum in the present study with inoculations on young branches. This discrepancy suggests different reactions among different plant organs or the condition of inoculation with or without injuries.

Mango accessions with a determined level of resistance to dieback disease may contribute to reduction in the source of the inoculum and limit the appearance of the stem-rot disease. According to Johnson et al. (1992), one of the causes of stemrot disease is internal colonization of panicles and peduncle from infected branches, and this can be limited by means of resistance.

An assumption had been made regarding the existence of mango cultivars in Florida with resistance in the field to tip dieback disease caused by Botryosphaeria ribis (Ramos et al., 1997). The present study is one of the first reports to consider simultaneous evaluations for two fungal causal agents that are important in Brazil.

\section{Conclusion}

The accessions ('Apple DCG', 'Ataulfo', 'Da porta', 'Dashehari', 'Espada', 'Haden', 'Haden 2H', 'Heidi', 'Irwin', 'Keitt', 'Kent', 'Néldica', 'Recife', and 'Smith') that exhibited double resistance to the two fungi can be used as sources of resistance in breeding studies or can even be more widely recommended for commercial growing, such as the varieties 'Ataulfo', 'Dashehari', 'Haden', 'Keitt', and 'Kent'.

Conflict of interest: All authors declare no conflict of interest

\section{References}

Alfenas, A. C.; Ferreira, F. A. 2007. Inoculação de fungos fitopatogênicos. p. 117-138. In: Alfenas, A. C.; Mafia, R. G. Métodos em fitopatologia. Viçosa: Universidade Federal de Viçosa

Anuário Brasileiro da Fruticultura. 2017. Santa Cruz do Sul, Gazeta do Sul

Batista, D. C.; Lima Neto, F. P.; Barbosa, J.; Amorim, C. C.; Barbosa, M. A. G. 2012. Avaliação da resistência de 47 acessos de mangueira aos fungos Fusicoccum aesculi e Neofusicoccum parvum. Revista Brasileira de Fruticultura 34 (3): 823-831 doi:10.1590/S0100-29452012000300023

Coelho, W.C.P.; Santos, C.A.F.; Batista, D.C. 2018. Inheritance of resistance to dieback disease in mango (Mangifera indica). Australian Journal $\begin{array}{llll}\text { of Crop Science } 12 & \text { (3): 467-471 }\end{array}$ doi:10.21475/ajcs.18.12.03.pne949

Costa, V.S.O.; Michereff, S.J.; Martins, R.B.; Gava, C.A.T.; Mizubuti, E.S.G.; Câmara, M.P.S. 2010. Species of Botryosphaeriaceae associated on mango in Brazil. European Journal of Plant Pathology 127 (4): 509-519. doi: 10.1007/s10658-010-9616-y 
Dhingra, O. D.; Sinclair, J. B. 1995. Basic plant pathology methods. Boca Raton, CRC Press.

Johnson, G. I.; Mead, A. J.; Cooke, A. W.; Dean, J. R. 1992. Mango stem end rot pathogens-fruit infection by endophytic colonization of the inflorescence and pedicel. Annals of Applied Biology 120 (2): 225-234

Khanzada, M. A.; Lodhi, A. M.; Rajput, A. Q.; Syed, R. N.; Shahzad, S. 2015. Response of different mango cultivars to mango decline pathogen, Lasiodiplodia theobromae PAT. International Journal of Biology and Biotechnology 12 (4): 643-647

Lima, J. A. S.; Oliveira, S. M. A.; Coelho, R. S. B.; Tavares, S. C. C. H. 1998. Comportamento de frutos de seis cultivares de mangueira inoculadas com Botryodiplodia theobromae PAT. Revista Brasileira de Fruticultura 20 (1): 108-111

Marques, M. W.; Lima, N. B.; Morais Júnior, M. A.; Barbosa, M. A. G.; Souza, B. O.; Michereff, S. J.; Phillips, A. J. L; Câmara, M. P. S. 2013. Species of Lasiodiplodia associated with mango in Brazil. Fungal Diversity 61 (1): 181-193. doi: 10.1007/s13225-013-0231-z

Ramos, L. J.; Davenport, T. L.; Mcmillan, R. T.; Lara, S. P. 1997. The resistance of mango (Mangifera indica) cultivars to tip dieback disease in Florida. Plant Disease 81 (5): 509-514

Siddiq, M.; Brecht, J. K.; Sidhu, J. S. 2017. Handbook of mango fruit: Production, postharvest Science, processing technology and nutrition. Chichester, John Wiley \& Sons

Slippers, B.; Wingfield, M. J. 2007. Botryosphaeriaceae as endophytes and latent pathogens of woody plants: diversity, ecology and impact. Fungal Biology Reviews. 21 (2-3): 90-106

Terao, D.; Batista, D. C.; Ribeiro, I. J. A. 2016. Doenças da mangueira (Mangifera indica L.). p. 523-533. In: Kimati, H.; Amorin, L.; Rezende, J. A. M.; Bergamin, Filho. A.; Camargo, L. E. A., eds. Manual de fitopatologia: doenças das plantas cultivadas. Ouro Fino, Agronômica Ceres

Valiela, M. V. F. 1952. Introducción a la fitopatologia. Buenos Aries, Talleres Gráficos

Yorinori, J. T.; Kiihl, R. A. S. 2001. Melhoramento de plantas visando resistência a doenças. p.715736. In: Nass, L. L.; Valois, A. C. C.; Melo, I. S.; Valadares-Inglis, M. C, eds. Recursos genéticos e melhoramento - plantas. Rondonópolis, Fundação MT

Cite this article as:

Coelho, W.C.P.; Santos, C.A.F.; Batista, D.C. 2020.

Variability of mango accessions resistance to dieback disease caused by Lasiodiplodia theobromae and Neofusicoccum parvum. Amaz. Jour. of Plant Resear. 4(1): 462-468.

Submit your manuscript at

https:// www.ajpr.online 